http://dx.doi.org/10.11646/zootaxa.3641.3.2

http://zoobank.org/urn:lsid:zoobank.org:pub:A93CEE37-186D-435C-BCBD-064224CD2C0F

\title{
Four new species of Aphelinidae (Hymenoptera: Chalcidoidea) from Mexico
}

\author{
SVETLANA NIKOLAEVNA MYARTSEVA, ENRIQUE RUÍZ-CANCINO \& JUANA MARÍA CORONADO- \\ BLANCO $^{1}$ \\ Facultad de Ingeniería y Ciencias, Universidad Autónoma de Tamaulipas, 87149 Cd. Victoria, Tamaulipas, México. \\ E-mail:smyartse@uat.edu.mx; eruiz@uat.edu.mx \\ ${ }^{1}$ Corresponding author. E-mail: jmcoronado@uat.edu.mx
}

\begin{abstract}
Four new species of Encarsia Förster (Hymenoptera: Aphelinidae) from Mexico are described-E. albata Myartseva sp. n. (State of Nuevo León), E. barracas Myartseva sp. n. (State of Baja California Sur), E. chichenitza Myartseva sp. n. (State of Yucatán) and E. elenae Myartseva sp. n. (State of Tamaulipas). A key to the species of Encarsia in Mexico published in 2012 is modified to include the newly described species.
\end{abstract}

Key words: Biodiversity, parasitic wasp, parasitoid, new species, North America

\section{Introduction}

Chalcidoidea is the largest superfamily of parasitic Hymenoptera, consisting of 22 families (Heraty et al. 2013). Several families of chalcid wasps contain species that are important for biological control of phytophagous insects in agricultural and natural ecosystems, and have been used against insect pests of various crops. Among Chalcidoidea, the family Aphelinidae is rivaled only by Encyrtidae in the number of species that have been used as effective parasitoids of insect pests (Greathead 1986).

Aphelinidae is a family of moderate diversity within Chalcidoidea, containing about 1,350 described species worldwide (Noyes 2012b). Aphelinids are primary parasitoids or hyperparasitoids of Insecta, mainly Hemiptera, especially Coccoidea and Aleyrodoidea, although some species are egg parasitoids of Lepidoptera and other orders of insects (Polaszek 1991; Gibson et al. 1997). At present, 184 species in 12 genera of Aphelinids are known to occur in Mexico (Myartseva et al. 2012).

Encarsia Förster, 1878 is classified in the tribe Pteroptricini, subfamily Coccophaginae of Aphelinidae (Hayat 1998). It is the most diverse genus of the family with 94 described species presently known from Mexico (Myartseva et al. 2012). Of these, more than 50 new species were found in the last ten years. It is also one of the largest and economically most important genera of Aphelinidae. In recent years the genus has been of increased interest for taxonomists and specialists in biological control and several papers and revisions were published in several different countries (Hayat 1998; Huang and Polaszek 1998; Schmidt and Polaszek 2007; Myartseva and Evans 2008). As a result, the number of known species of Encarsia increased from 146 in 1980 to 410 in 2012 (Noyes 2012a). Many species have been associated with classical biological control programs throughout the world against pests belonging to the hemipteran families Aleyrodidae and Diaspididae (Altieri and Nicholls 1999). Several species were introduced into Mexico to control whiteflies and armored scale insects in citrus (Myartseva and Ruíz-Cancino 2000).

In this article, four new species of Encarsia from four different states of Mexico (Baja California Sur, Nuevo León, Tamaulipas, Yucatán), are described as new. 


\section{Material and methods}

This study is based on material obtained from the aphelinid collection in the entomological museum of the Universidad Autónoma de Tamaulipas, Victoria, México (UAT), which contains more than 1,000 aphelinids mounted on slides and several thousands in ethanol, reared from hosts during 14 years in 16 Mexican States. Of the specimens, $80 \%$ are Encarsia. We also collected colonies of hemipterans on leaves of various plants in November 2007, in Tinum, State of Yucatán. The infested leaves were placed in plastic containers and transferred to the laboratory where emerged parasitoids and the hemipteran hosts collected earlier were preserved in $75 \%$ ethanol. From this sample, a single specimen was reared, representing one new species (E. chichenitza). Aphelinids were also sorted from a Malaise trap set up in Gómez Farías, State of Tamaulipas, from June to August 2000, but aphelinids were practically absent with only one specimen of Encarsia corresponding to one new species (Encarsia elenae). Finally, the senior author received on loan 243 Encarsia, including material from Santiago, State of Nuevo León, and Los Cabos, State of Baja California Sur from the Entomological Museum Research of the University of California, Riverside, USA (UCRC) mounted on paper. Two groups of specimens with different coloration were represented -157 with the body completely yellow and 86 with some dark or infuscate parts. From this last group, 56 were male (identification not possible); the rest represented six species-E. inaron (Walker) (17 specimens), $E$. macula Myartseva \& Evans (5), E. luteola Howard (4), E. juanae Myartseva \& Evans (2) and the two new species, E. albata (1) and E. barracas (1). Some specimens were cleared and dissected for mounting on microscopic slides in Canada balsam following the method of Noyes (1982).

Absolute measurements are used only for body length. Relative measurements are given for dimensions of body parts-wings, antennal segments, legs, ovipositor, etc., which were measured with divisions of a linear scale of a micrometer placed in a Leica CME compound microscope. Illustrations of some body parts were made using a RA-4 drawing apparatus at $280 \times$ magnification. Drawings of all figures were made at the same magnification. Specimens were identified using keys to Encarsia species of Myartseva et al. (2012), Hayat (2012) and Schmidt and Polaszek (2007). Holotypes of all new species will be deposited in UCRC.

\section{Results and discussion}

\section{Encarsia Förster 1878}

Remarks. See Noyes (2012) for generic synonymy.

Diagnosis. Encarsia is recognized by the following combination of morphological characters: head in frontal view distinctly wider than high, dorsum transverse; mandible with 3 teeth, 2 teeth and a truncation, or very rarely four teeth; female antenna 8-segmented, with scape cylindrical; mid lobe of mesoscutum with 2 to more than 30 setae, but usually with $6-12$; scutellum wider than long, with 2 pairs of setae and 1 pair of placoid sensilla; submarginal vein of fore wing usually with 2 setae, marginal vein longer than submarginal and with variable number of setae, postmarginal vein absent, stigmal vein very short, disc densely setose; legs with tarsi 5-segmented or mid tarsus 4-segmented; gaster with 7 terga; ovipositor exerted or not, relative lengths of third valvula and second valvifer variable. Male similar to female except for genitalia and antennal flagellum. Body color in both sexes variable; wings hyaline or infuscate; body never strongly sclerotized and metallic, length $0.5-2 \mathrm{~mm}$.

\section{Modified key to species of Encarsia of Mexico by Myartseva et al. (2012)}

Couplet:

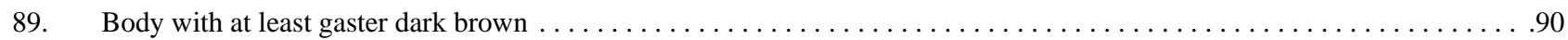

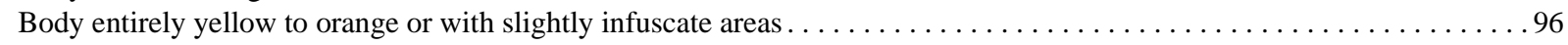

90. Fore wing infuscate behind marginal vein; first flagellar segment quadrate to slightly longer than wide; midtibial spur $0.7 \times$ as long as basitarsus of mid tarsus; parasitoids of Aleyrodidae . . . . . . . . . . . . . . ..smithi group...68. E. smithi (Silvestri) Fore wing hyaline; first flagellar segment cylindrical; midtibial spur length variable; parasitoids of Diaspididae . . . . . .91

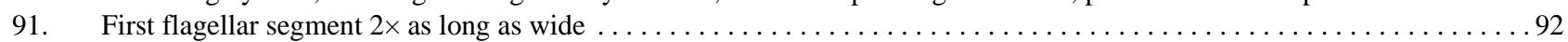

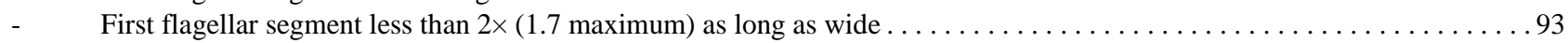

92. Second flagellar segment visibly shorter than first segment and shorter than third segment, and $1.3 \times$ as long as wide; club $3-$ 
segmented and longer than funicle; ovipositor as long as mid tibia ................ 3. E. ameca Myartseva Second flagellar segment as long as first and third segments, and $2 \times$ as long as wide; club 2 -segmented and slightly longer than

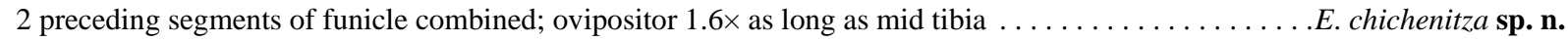

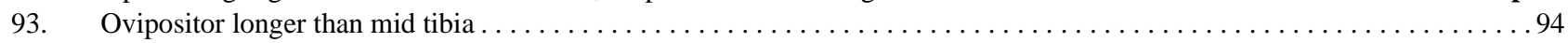

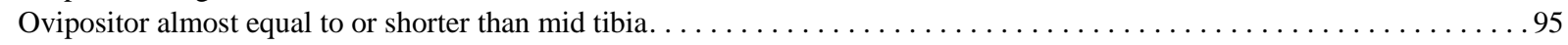

94. Ovipositor $1.4 \times$ as long as mid tibia; third valvula $0.4 \times$ as long as second valvifer; second and third flagellar segments each about as long as wide (1.1x); scape $4.4 \times$ as long as wide; fore wing with 3 basal groups of setae; midtibial spur subequal to

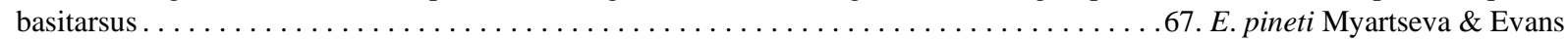
Ovipositor $1.7 \times$ as long as mid tibia; third valvula $0.5 \times$ as long as second valvifer; third flagellar segment the longest, longer than second segment and $2.5 \times$ as long as wide; scape $5.4 \times$ as long as wide; fore wing with 7 or 8 basal groups of setae; midtib-

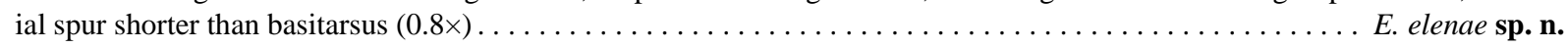

95. Ovipositor $0.8 \times$ as long as mid tibia; third valvula $0.7 \times$ as long as second valvifer; mid lobe of mesoscutum with 6 setae; marginal fringe of fore wing $0.5 \times$ as long as maximum width of wing; midtibial spur shorter than basitarsus. . . . . . . . . .

25. E. escama Myartseva Ovipositor subequal in length to mid tibia; third valvula $0.5 \times$ as long as second valvifer; mid lobe of mesoscutum with 8 setae; marginal fringe of fore wing $0.3-0.4 \times$ as long as maximum width of wing; midtibial spur as long as basitarsus. . . . . . . .

39. E. juanae Myartseva \& Evans

96. First flagellar segment as long as second segment, both $2 \times$ as long as wide; base of fore wing with 9-12 setae; marginal vein with 8-10 setae along anterior margin; mesosoma and gaster with some infuscate parts.... 68. E. pitilla Myartseva \& Evans First flagellar segment not subequal to second segment and 1.4-1.6x as long as wide; base of fore wing with 3-5 setae; marginal vein with 5-7 setae along anterior margin; mesosoma and gaster without infuscate parts.. . . . . . . . . . . 97

97. Mid tibial spur $0.7 \times$ as long as basitarsus of mid tarsus; marginal vein of fore wing with 5 setae along anterior margin; gastral dorsum with weakly imbricate lateral margins on all tergites............. 59. E. neoporteri Myartseva \& Evans Mid tibial spur 1.0-1.8× as long as basitarsus of mid tarsus; marginal vein of fore wing with 6 or 7 setae along anterior margin;

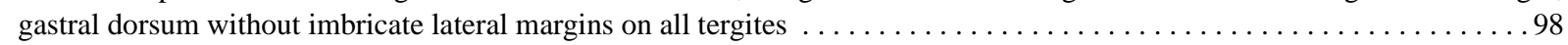

98. Pedicel $0.5 \times$ as long as first segment of flagellum; club longer than funicle; mid tibial spur $0.8 \times$ as long as basitarsus; oviposi-

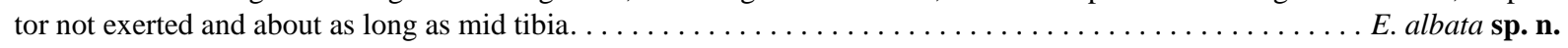
Pedicel only slightly longer than first segment of flagellum; club shorter than funicle; midtibial spur as long as basitarsus; ovipositor exerted and $1.4 \times$ as long as mid tibia $\ldots \ldots \ldots \ldots \ldots \ldots \ldots \ldots \ldots \ldots \ldots \ldots \ldots \ldots \ldots \ldots \ldots \ldots \ldots \ldots \ldots$ barracas $\mathbf{s p}$.

\section{Description of new species}

\section{Encarsia albata Myartseva, sp. n.}

(Figs 1-4)

Material. Holotype female: México, Nuevo León, (Santiago), Puerto Genovevo, 17.V.1984 (col. G. Gordh), UCRC Ent. N 54394.

Length of body $=0.8 \mathrm{~mm}$.

Coloration. Head yellow, ocelli reddish, eyes brown, antennae yellow. Mesosoma light yellow. Fore wing hyaline. Legs light yellow to pale. Gaster light yellow, apices of stylets blackish.

Structure. Head not wider than mesosoma, about $1.4 \times$ as wide as high. Frontovertex about $0.6 \times$ as wide as head. Eye about as long as cheek. Distance between toruli about $0.6 \times$ as long as distance from torulus to eye margin. Antennae (Fig. 1) inserted under level of lower margin of eyes. Antennal radicle $2.4 \times$ as long as wide. Scape about $4 \times$ as long as wide. Pedicel $1.7 \times$ as long as wide and $1.5 \times$ as long as first funicle segment. First funicle segment about $1.4 \times$ as long as wide, second and third segments subequal in length, $1.6 \times$ and $1.4 \times$ as long as wide, respectively. Club 3-segmented, slightly wider and longer than funicle. Flagellum with segments $2-6$ each with one longitudinal sensillum. Mid lobe of mesoscutum with 4 pairs of setae, placed symmetrically. Scutellum about $0.8 \times$ as long as mid lobe of mesoscutum and about $0.7 \times$ as wide as long. Scutellar placoid sensilla widely spaced. Anterior pair of scutellar setae slightly shorter than posterior pair, and distance between bases of anterior setae about $0.7 \times$ as long as the distance between bases of posterior setae. Fore wing uniformly setose and $3 \times$ as long as maximum width of wing, marginal fringe $0.3 \times$ as long as width of wing, base with 5 setae. Marginal vein (Fig. 2) with 6 setae along anterior margin. Marginal fringe of hind wing about as long as maximum width of wing. Tarsal formula 5-5-5. Mid tibial spur $0.8 \times$ as long as basitarsus of mid tarsus (Fig. 3). Ovipositor (Fig. 4) not exerted, about as long as mid tibia. Third valvula about $0.5 \times$ as long as second valvifer.

Male unknown.

Comments. Encarsia albata sp. n. is similar to E. pitilla Myartseva \& Evans, but can be distinguished by the following complex of characters: mesosoma and gaster light yellow versus with infuscate parts; mid lobe of 
mesoscutum with 8 versus 4-6 setae; base of fore wing with 5 versus 9-12 setae, marginal vein with 6 versus $8-10$ setae along anterior margin; midtibial spur $0.8 \times$ versus subequal in length to basitarsus; and third valvula $0.5 \times$ versus $0.2-0.3 \times$ as long as second valvifer.

Etymology. The species named is based on the very light, pale color of the body.
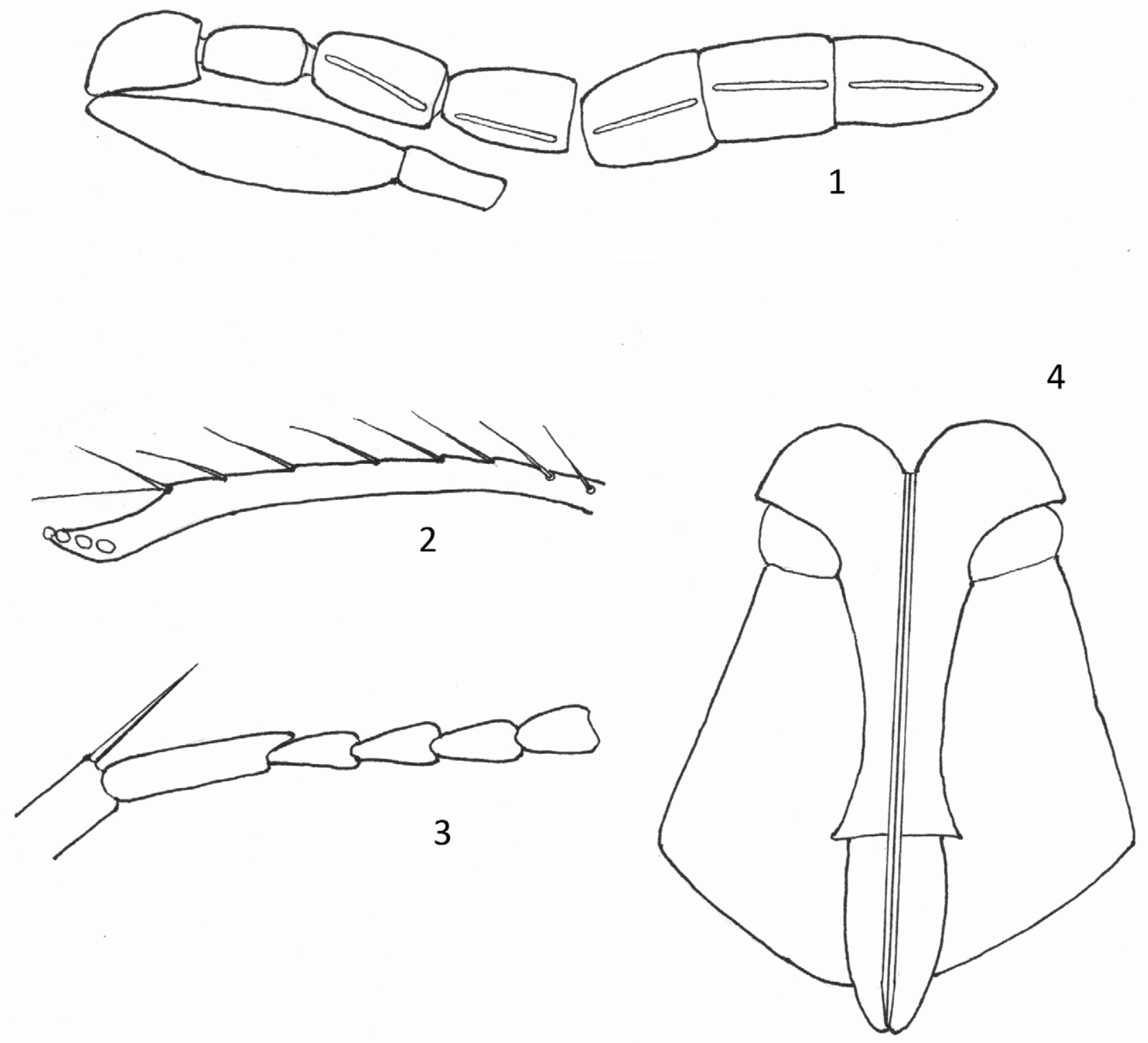

FIGURES 1-4. Encarsia albata, sp. n., female: 1, antenna; 2, marginal vein; 3, mid tarsus; 4, ovipositor.

\section{Encarsia barracas Myartseva, sp. $n$.}

(Figs 5-8)

Material. Holotype female: Mexico, Baja California Sur, (Los Cabos), Las Barracas, in pan trap, 14. V. 1984 (col. P. DeBach), UCRC Ent. N 54486.

Length of body (without ovipositor) $=0.7 \mathrm{~mm}$.

Coloration. Head yellow, face below lighter, antennae light yellow. Mesosoma yellow. Fore wing hyaline. Legs light yellow. Gaster yellow. Ovipositor sheath infuscate.

Structure. Head slightly wider than mesosoma, $1.3 \times$ wider than high; frontovertex transversely striate, about $0.5 \times$ as wide as head. Ocelli in obtuse triangle; distance between posterior ocelli about $1.6 \times$ as long as distance from ocellus to eye margin. Eye about as long as cheek. Mandible with 3 large teeth. Distance between toruli about 


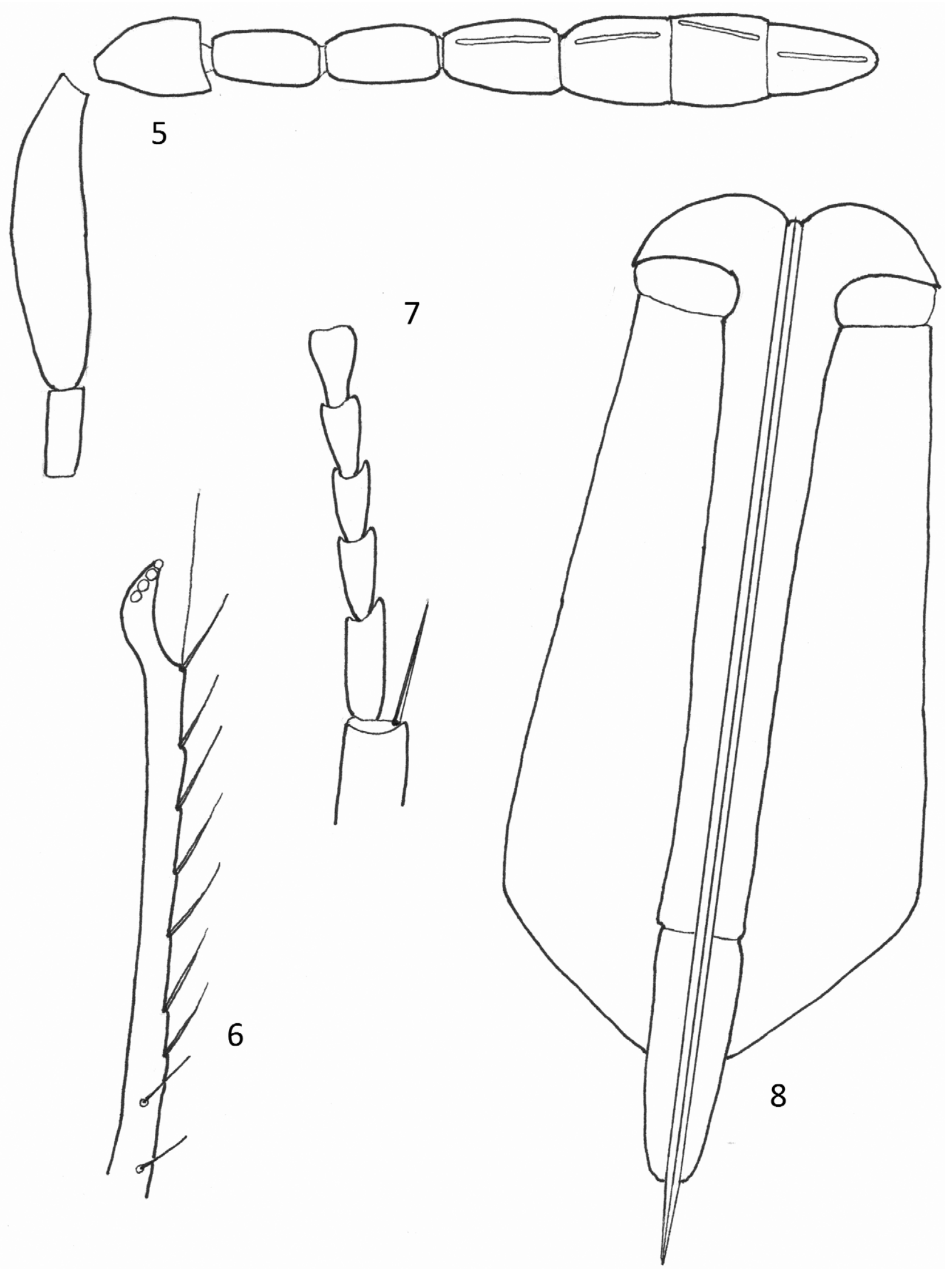

FIGURES 5-8. Encarsia barracas, sp. n., female: 5, antenna; 6, marginal vein; 7, mid tarsus; 8, ovipositor. 
$0.8 \times$ as long as distance from torulus to eye margin. Antennae (Fig. 5) inserted below level of lower margin of eyes; radicle $2.4 \times$ as long as wide; scape about $4 \times$ as long as wide; pedicel $1.3 \times$ as long as wide; funicle with first segment slightly shorter than pedicel, about $1.6 \times$ as long as wide, second and third segments subequal in length, $1.6 \times$ as long as wide, with second segment slightly longer than first segment and slightly shorter than third segment, but both second and third segments1.5x as long as wide; club 3-segmented, slightly wider and shorter than funicle; flagellum with segments 3-6 each with one longitudinal sensilla. Mesoscutum with 4 pairs of setae on mid lobe, placed symmetrically, and 3 setae on each side lobe. Axilla with 1 seta. Scutellum about $0.7 \times$ as long as mid lobe of mesoscutum and about $0.9 \times$ as wide as long; placoid sensilla widely spaced; anterior pair of setae about $0.6 \times$ as long as posterior pair of setae; distance between bases of anterior setae about $1.3 \times$ as long as distance between bases of posterior setae. Fore wing uniformly setose with short setae; about $2.8 \times$ as long as maximum width of wing; marginal fringe about $0.2 \times$ as long as width of wing; base with 4 setae; marginal vein (Fig. 6) with 7 setae along anterior margin. Hind wing $5 \times$ as long as maximum width of wing; marginal fringe slightly longer than width of wing. Tarsal formula 5-5-5. Middle leg with tibial spur about as long as basitarsus (Fig. 7); basitarsus as long as following two tarsal segments combined. Hind leg with basitarsus about as long as following three tarsal segments combined. Ovipositor (Fig. 8) exerted, about $1.4 \times$ as long as mid tibia; third valvula about $0.3 \times$ as long as second valvifer.

Male unknown.

Comments. Encarsia barracas sp. n. is similar to E. pitilla Myartseva \& Evans and to E. albata sp. n. It can be distinguished from E. pitilla by following complex of characters: head and body yellow versus with some infuscated parts; club shorter than versus longer than funicle; fore wing with marginal fringe $0.2 \times$ versus $0.4 \times$ as long as maximum width of wing; marginal vein with 7 versus $8-10$ setae along anterior margin; base of wing with 4 versus 9-12 setae; marginal fringe of hind wing slightly longer versus $1.8 \times$ longer than width of wing; and ovipositor $1.4 \times$ versus $1.1 \times$ as long as mid tibia. Differences between $E$. barracas $\mathbf{s p . ~ n . ~ a n d ~ E . ~ a l b a t a ~} \mathbf{s p . ~ n . ~ a r e ~}$ given in the key (see above).

Etymology. The species is named after the type locality, Las Barracas.

\section{Encarsia chichenitza Myartseva, sp. n.}

(Figs 9-12)

Material. Holotype female: México, Yucatán, (Tinum), Chichén Itzá, 15.XI.2007, ex Diaspididae on tree (S.N. Myartseva). Holotype deposited in UCRC.

Length of body $=0.7 \mathrm{~mm}$.

Coloration. Head brownish, frontovertex above and cheeks darker. Antennae light yellow. Mesosoma brown, side lobe and scutellum yellow. Fore wing hyaline, venation light colored. Leg light yellow; fore coxa yellow, mid coxa brownish, hind coxa brown. Gaster brown. Ovipositor sheath brown. Setae yellow on yellow parts of body and dark brown on brown parts.

Structure. Head not wider than mesosoma, $1.3 \times$ as wide as long. Frontovertex with tiny transverse striate sculpture behind ocelli and $0.6 \times$ as wide as head. Eye $1.4 \times$ as long as cheeks. Mandible with three small teeth. Antennae (Fig. 9) inserted at the level of lower margin of eyes. Distance between toruli about $0.7 \times$ as long as distance from torulus to eye margin. Antennal radicle short, $1.4 \times$ as long as wide. Scape about $4 \times$ as long as wide. Pedicel about $1.6 \times$ as long as wide and shorter than first funicle segment. First-fourth funicle segments each $2 \times$ as long as wide. Club 2-segmented, with slightly longer segments, and slightly longer than the two preceding segments of funicle combined. All funicle segments with one longitudinal sensilla, segments of club with two sensilla each. Mid lobe of mesoscutum with 12 setae, setae at upper and lower corners longer. Sculpture of mid lobe of mesoscutum and axillae large reticulate. Side lobes with 3 setae each, axillae with one seta each. Scutellum $0.8 \times$ as long as mid lobe of mesoscutum and about $2 \times$ as wide as long. Scutellar placoid sensilla small and widely spaced. Distance between bases of anterior scutellar setae about $0.8 \times$ as long as the distance between bases of posterior setae. Anterior pair of setae $0.5 \times$ as long as the posterior pair of setae. Fore wing uniformly setose and $2.8 \times$ as long as maximum width of wing, marginal fringe about $0.2 \times$ as long as width of wing, base with 5 setae. Marginal vein (Fig. 10) slightly longer than submarginal vein and with 7 setae along anterior margin. Hind wing $7.6 \times$ as long as wide, its marginal fringe about $1.4 \times$ as long as maximum width of wing. Tarsal formula 5-5-5. Mid tibial spur $0.8 \times$ as long as basitarsus of mid tarsus (Fig. 11); first tarsal segment as long as 3 next segments 
combined. Gastral tergites T2-T7 with 1, 1, 1, 4, 4 and 4 setae on each side, respectively. Ovipositor (Fig. 12) almost not exerted, about $1.6 \times$ as long as mid tibia; third valvula with apical setae and about $0.3 \times$ as long as second valvifer.

Male unknown.

Comments. Encarsia chichenitza $\mathbf{s p . ~ n . ~ i s ~ s i m i l a r ~ t o ~ E . ~ p i n e t i ~ M y a r t s e v a ~ \& ~ E v a n s , ~ w h i c h ~ w a s ~ d e s c r i b e d ~ f r o m ~}$ the State of Tamaulipas. The holotype of the new species was compared with holotype female of E. pineti and is easily separated by the following complex of characters: mesosoma mostly brown versus mostly yellow; all segments of funicle $2 \times$ versus less than $2 \times$ as long as wide; club 2-segmented versus 3 -segmented; mid lobe of mesoscutum with 12 setae versus 6 setae, midtibial spur shorter than versus subequal in length to basitarsus; ovipositor $1.6 \times$ versus $1.4 \times$ as long as mid tibia.

Etymology. The species is named after the type locality, Chichén Itzá.

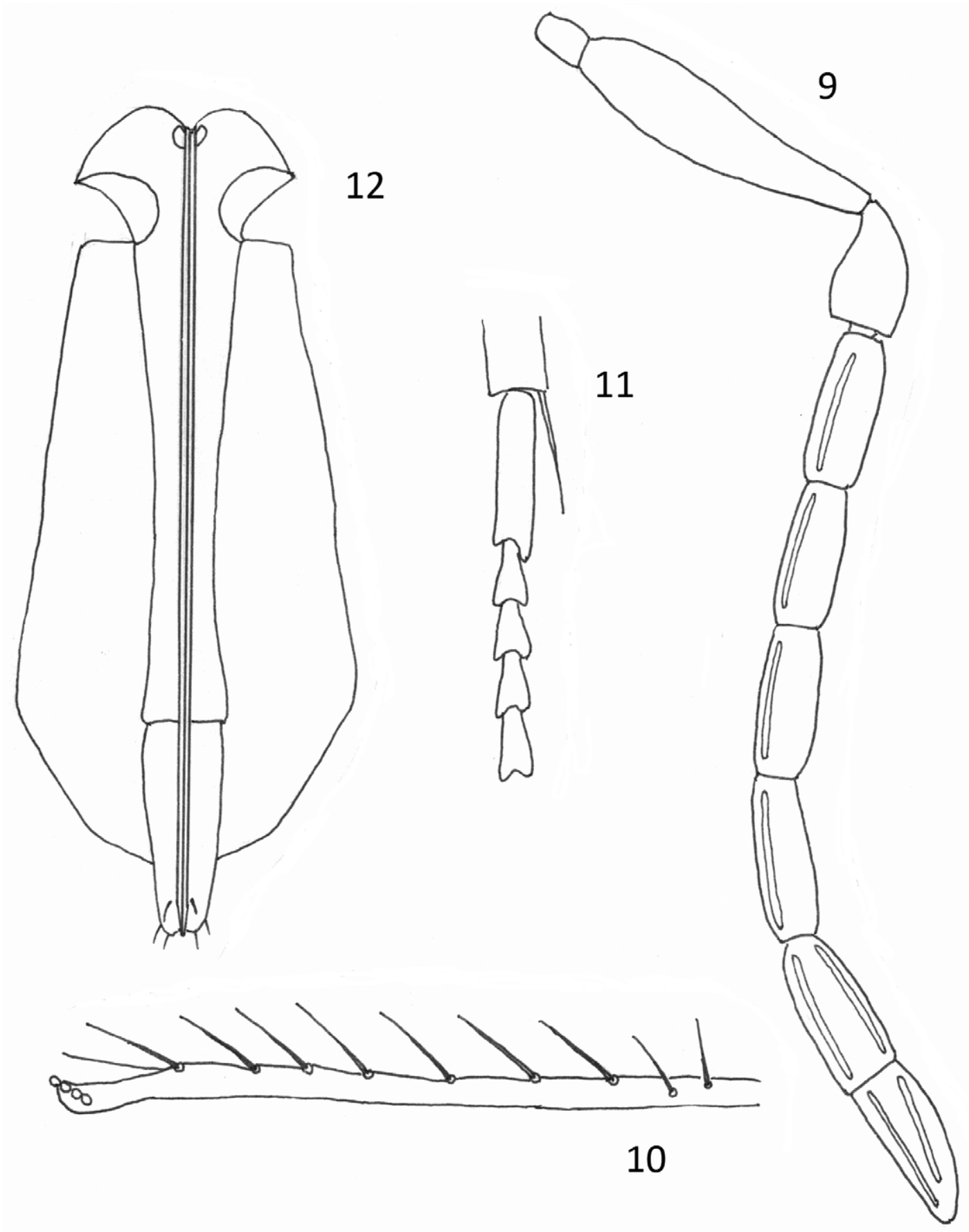

FIGURES 9-12. Encarsia chichenitza, sp. n. , female: 9, antenna; 10, marginal vein; 11, mid tarsus; 12, ovipositor. 


\section{Encarsia elenae Myartseva, sp. n.}

(Figs 13-16)

Material. Holotype female: México, Tamaulipas, (Gómez Farías), Altas Cimas (900 m), Malaise trap, 412.VIII.2000 (D.R. Kasparyan). Holotype deposited in UCRC.

\section{Length of body (without ovipositor) $=0.8 \mathrm{~mm}$.}

Coloration. Head yellow, frontovertex orange, ocelli reddish, occiput above foramen infuscate. Antennae grayish yellow. Mesosoma yellow, anterior part of mid lobe of mesoscutum, axillae, and propodeum infuscate. Fore wing hyaline, venation slightly infuscate. Legs light yellow. Gaster brown. Ovipositor with valvulae light yellow.

Structure. Head very slightly wider than mesosoma, about $1.5 x$ as wide as high. Frontovertex with transversely striate sculpture, about $0.5 \times$ as wide as width of head. Ocelli large. Distance between hind ocelli, which are situated in small triangle, about $0.3 \times$ as long as distance from hind ocellus to eye. Eye about $1.6 \times$ as long as cheek. Mandible with three large teeth. Antennae (Fig. 13) inserted below level of lower margin of eyes. Distance between toruli about $0.5 \times$ as long as distance from torulus to eye margin. Antennal radicle long, about $3.7 \times$ as long as wide. Scape $5.4 \times$ as long as wide. Pedicel about $2.4 \times$ as long as wide and about $1.5 \times$ as long as first funicle segment. First and second segments of funicle about equal in length and width, and both slightly less than $2 \times$ as long as wide (1.7 and 1.8, respectively). Third funicle segment the longest, about $2.5 \times$ as long as wide. Club 3 -segmented, not wider than funicle and slightly shorter than funicle and pedicel combined. Third funicle segment with one longitudinal sensillum, segments of club with two sensilla each. Mid lobe of mesoscutum with 6 setae. Sculpture of mid lobe and axillae reticulate. Side lobes with 3 setae each, axillae with one seta each. Scutellum $0.7 \times$ as long as mid lobe of mesoscutum and about $2 x$ as wide as long. Scutellar placoid sensilla large and widely spaced, separated by a distance of 5 diameters of one sensillum. Distance between bases of anterior scutellar setae slightly longer (28:25) than distance between bases of posterior setae, and anterior pair of setae $0.5 \times$ as long as posterior pair of setae. Fore wing uniformly setose and $2.7 \times$ as long as maximum width of wing, marginal fringe about $0.3 \times$ as long as width of wing, base with 7 or 8 setae. Marginal vein (Fig. 14) slightly longer than submarginal vein (13:11) and with 6 setae along anterior margin. Hind wing about $6.3 \times$ as long as maximum width of wing, its marginal fringe slightly longer than maximum width of wing (31:28). Tarsal formula 5-5-5. Mid tibial spur about $0.8 \times$ as long as basitarsus of mid tarsus (Fig. 15). Gastral tergites T2-T7 with 1, 1, 1, 4, 2 and 4 setae on each side, respectively. Ovipositor(Fig. 16) largely exerted, about $1.7 \times$ as long as mid tibia; third valvula about $0.5 \times$ as long as second valvifer.

Male unknown.

Comments. Encarsia elenae sp. n. is close to E. pineti Myartseva \& Evans, described from the State of Tamaulipas and collected also in the Biosphere Reserve "El Cielo". The holotype of the new species was compared with the holotype female of E. pineti and is easily separated by the following complex of characters: scape $5.4 \times$ versus $4.4 \times$ as long as wide, third funicle segment the longest, longer than the second segment and $2.5 \times$ as long as wide versus second and third funicle segments very short and both $1.1 \times$ as long as wide, fore wing with 7 or 8 versus 3 basal groups of setae, midtibial spur shorter versus subequal in length to basitarsus, ovipositor largely versus slightly exerted, $1.7 \times$ versus $1.4 \times$ as long as mid tibia, and third valvula $0.5 \times$ versus $0.4 \times$ as long as second valvifer.

Etymology. Named in honour of the first daughter of the senior author, Elena Myartseva, living in Minsk, Belarus.

\section{Acknowledgements}

To Dr. Serguei V. Triapitsyn (UCRC Entomological Museum), for the loan of specimens of Aphelinidae collected in Mexico during several years. To PROMEP project "Taxonomy and ecology of fauna and mycobiota in forest communities and crops of Mexico" and to Universidad Autónoma de Tamaulipas, México, for financial support. To the reviewers and the editor for their excellent revision of this paper. 

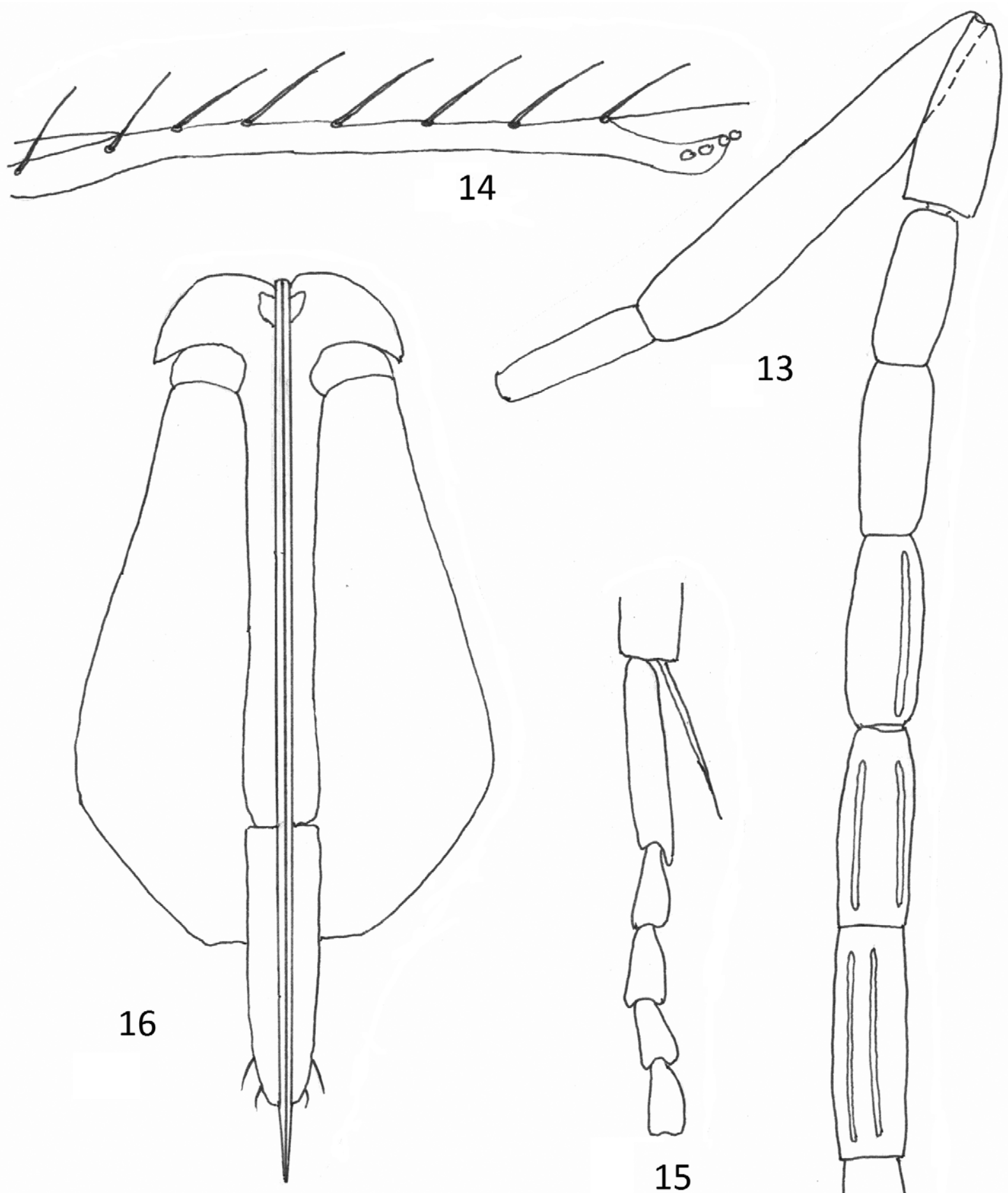

13

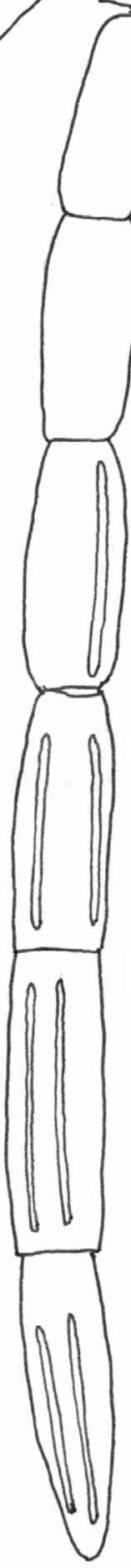

FIGURES 13-16. Encarsia elenae, sp. n. , female: 13, antenna; 14, marginal vein; 15, mid tarsus; 16, ovipositor. 


\section{References}

Altieri, M.A. \& Nicholls, C.Y. (1999) Classical biological control in Latin America. In: Bellows, T.S. and Fisher, T.W. (Eds.). Handbook of biological control, Academic Press, London, UK, pp. 975-991.

Förster, A. (1878) Kleine Monographien parasitischer Hymenopteren. Verhandlungen der Naturhistorischen Vereins der Preussischen Rheinlande und Westfalens, 35, 42-82.

Gibson, G.A.P, Huber J.T. \& Woolley J.B. (Eds.). (1997) Annotated keys to the genera of Nearctic Chalcidoidea (Hymenoptera). NRC Research Press, Ottawa, Canada, 794 pp.

Greathead, D. (1986) Parasitoids in classical biological control. In: Waage, J. \& D. Greathead (Eds.). Insect parasitoids. Academic Press, London, pp. 289-318.

Hayat, M. (1998) Aphelinidae of India (Hymenoptera: Chalcidoidea): a taxonomic revision. Memoirs on Entomology, International. Associated Publishers, Gainesville, Florida, U.S.A., 13, 1-416.

Hayat, M. (2012) Additions to the Indian Aphelinidae (Hymenoptera: Chalcidoidea) - III: The genus Encarsia Förster. Oriental Insects, 45, 202-274. http://dx.doi.org/10.1080/00305316.2011.630212

Heraty J.M., R.A. Burks, A. Cruaud, G. A. P. Gibson, J. Liljeblad, J. Munro, J.Y. Rasplus, G. Delvare, P. Jansta, A. Gumovsky, J. Huber, J. B. Woolley, L. Krogmann, S. Heydon, A. Polaszek, S. Schmidt, D. C. Darling, M. W. Gates, J. Mottern, E. Murray, A. D. Molin, S. Triapitsyn, H. Baur, J. D. Pinto, S. van Noort, J. George \& M. Yoder (2013) A phylogenetic analysis of the megadiverse Chalcidoidea (Hymenoptera). Cladistics, 1-77.

Huang, J. \& Polaszek A. (1998) A revision of the Chinese species of Encarsia Foerster (Hymenoptera: Aphelinidae): parasitoids of whiteflies, scale insects and aphids (Hemiptera: Aphelinidae, Diaspididae, Aphidoidea). Journal of Natural History, 32, 1825-1966. http://dx.doi.org/10.1080/00222939800770911

Myartseva, S.N. \& Evans G.A. (2008) Genus Encarsia Förster of Mexico (Hymenoptera: Chalcidoidea: Aphelinidae). A revision, key and description of new species. Serie Avispas Parasíticas de Plagas y otros Insectos No. 3. Universidad Autónoma de Tamaulipas, Ciudad Victoria, México, 320 pp.

Myartseva, S.N. \& Ruíz-Cancino E. (2000) Annotated checklist of the Aphelinidae (Hymenoptera: Chalcidoidea) of Mexico. Folia Entomológica Mexicana, 109, 7-33.

Myartseva, S.N., Ruíz-Cancino E. \& Coronado-Blanco J.M. (2012) Aphelinidae (Hymenoptera: Chalcidoidea) de importancia agrícola en México. Revisión y claves. Serie Avispas Parasíticas de Plagas y otros Insectos No. 8. Universidad Autónoma de Tamaulipas, México, 413 pp.

Noyes, J.S. (1982) Collecting and preserving chalcid wasps (Hymenoptera: Chalcidoidea). Journal of Natural History, 16, $315-334$. http://dx.doi.org/10.1080/00222938200770261

Noyes, J.S. (2012a) Universal Chalcidoidea Database. World Wide Web electronic publication. http://www.nhm.ac.uk/ chalcidoids

Noyes, J.S. (2012b) An inordinate fondness of beetles, but seemingly even more fond of microhymenoptera! Hamuli, The Newsletter of the International Society of Hymenopterists, 3, 5-8.

Polaszek, A. (1991) Egg parasitism in Aphelinidae (Hymenoptera: Chalcidoidea) with special reference to Centrodora and Encarsia species. Bulletin of Entomological Research, 81, 97-106. http://dx.doi.org/10.1017/S0007485300053293

Schmidt, S. \& Polaszek A. (2007) The Australias species of Encarsia Förster (Hymenoptera, Chalcidoidea: Aphelinidae), parasitoides of whiteflies (Hemiptera, Sternorrhyncha, Aleyrodidae) and armoured scale insects (Hemiptera, Coccoidea: Diaspididae). Journal of Natural History, 41, 2099-2265.

http://dx.doi.org/10.1080/00222930701550766 